\title{
Experimental Study on Stress Relief by Advanced Boring Bored Near Fracture Zone
}

\author{
by Sohei SHIMADA ${ }^{1}$
}

1. Faculty of Engineering, The University of Tokyo, Bunkyo-ku, Tokyo 113

Stress relief method is widely used in coal mines in many countries to prevent the gas outburst and rock burst. It is one of the effective methods to relieve the stress by boring in coal seams.

The author made a model experiment to investigate the effect of the boring bored near fractured zone at the heading face on the stress relief. A three-dimensional model experimental apparatus of about 1:80 geometrical scale was used. As the model rock mass, the gypsum plate was used and as the model coal seam, an artificial seam made from the mixture of water, gypsum and diatomite was used. The scale factor of the stress and strength was 1:40. The effect of the stress relief was measured by varying the location of fractured zone, the thickness of fractured zone and the strength of model coal seam.

The effect of the stress relief was evaluated by the degree of stress relief defined by the author. The characteristics of the stress distribution near the fractured zone and the relationship between the degree of the stress relief and the above experimental parameters were reported.

KEY WORDS: Stress Relief, Model Experiment, Advanced Boring, Fractured Zone

\section{1. ま え がき}

ガス突出防止対策としての先進ボーリングやスリットによる応 力解放の効果は, 諸外国および我が国でも確認され, 報告されて いる1）。特に, 我が国においては, 石炭技術研究所が赤平炭鉱で

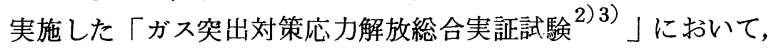
大口径ボーリングによる応力解放効果が確かめられている。また， この実証試験においては, 応力解放ボーリング孔付近に破碎帯 (断層) 等の不連続面が存在すると, その面を境にして応力解放 がみられる領域と, そうでない領域に分割されるという結果も得 られている。

現場において応力解放の効果を定量的に測定することは, 時間 および経費の面から容易ではない。この点, 模型実験では同条件 下での実験を比較的容易に行うことができる。このような観点か ら, 破砕帯付近に作孔した先進ボーリングによる応力解放効果に つき, 3 次元模型実験装置を用いて実験した。

実験では, 破碎帯の厚さ, 破碎帯の位置, 模型炭層強度を変化 させた。応力解放効果は, 先進ボーリングを行った場合の切羽前 方の応力分布の変化をもとに, 応力解放度を用いて定量的に評価 した。現場の応力解放作業では, 坑道掘進方向に交差する破砕帯 前後の応力解放が, 保安面から最も重要であると考えられるが, 坑道掘進方向に交差する破碎帯の製作が非常に困難であったため,

* 1991 年 8 月 6 日受付 12 月 3 日受理

1. 正会員 工博 東京大学助教授 工学部資源開発工学科

キーワード : 応力解放, 模型実験, 先進ボーリング, 破砕帯
破砕帯が掘進方向と平行して走っている場合を想定し，実験を行 った。

なお，この実験では模型化が難しい炭層内のガスの影響，すな わち, ガス湧出，ガス脱着等の影響は考虑していない。

\section{2. 実験装置・方法}

\section{$2 \cdot 1$ 本体}

実験装置本体の概略図を図 1 に示す。装置本体は 3 直交軸方向 に対応する 3 対の加圧プレートと，これを押すための油圧ジャッ キ群からなる。加圧状態で坑道やボーリング孔を作孔でさるよう に, 前面プレートには半円形の開放部を設けてある。油圧ジャッ キは全部で12本設置されており，4本ずつの 3 群に分かれて，そ れぞれ直交する 3 方向から載荷できるようになっている。油圧ポ ンプの最高圧力 $70 \mathrm{MPa}$, ジャッキ 1 本当たり最大荷重 $20 \mathrm{kN}$ であ

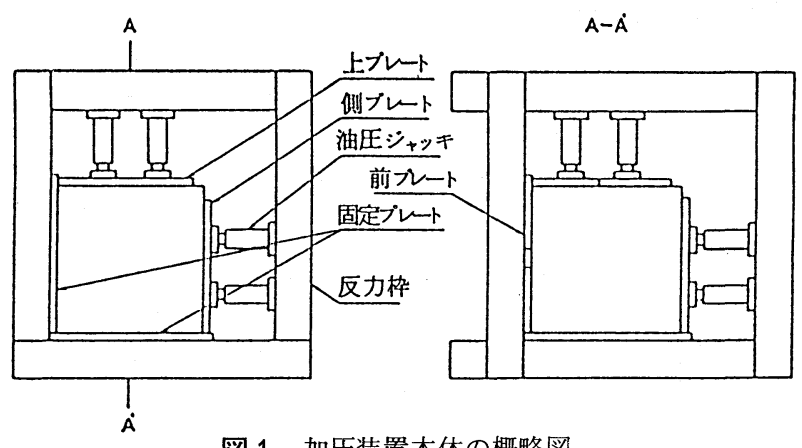

図 1 加圧装置本体の概略図 


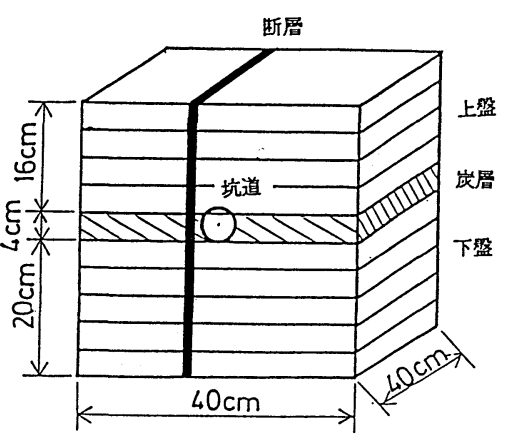

図2 模型試料配置図

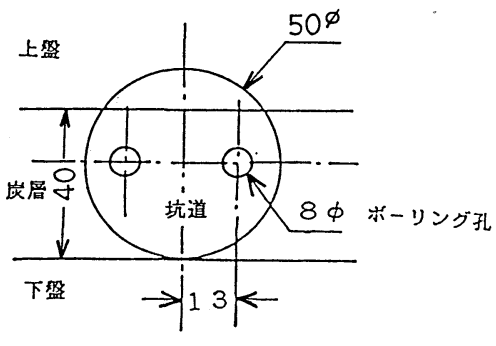

図3掘進切羽面でのボーリング孔規格 (単位 $: \mathrm{mm}$ )

る。

\section{$2 \cdot 2$ 地層模型}

縮尺地層模型（図 2）は以下のような標準的な坑道掘進切羽を 想定して製作した。

1) 深度 : $600 \mathrm{~m}$ (かぶり圧 $15 \mathrm{MPa}$ )

2) 炭たけ：3. $2 \mathrm{~m}$

3) 炭層の王縮強度：4〜12 $\mathrm{MPa}$

4）上下盤の圧縮強度 : $60 \mathrm{MPa}$

模型実験の幾何学的縮尺比は $1: 80$, また王縮強度および応力 の模型と原型の相似比は 1:40 とした。模型材料のうち, 上下盤 岩石としては厚さ $4 \mathrm{~cm}$ の石膏建材を用いた。炭層および破砕帯 には水, 石膏, 珪藻土の混合比を変えて適当な強度に調整した模 型試料を用いた。これらの試料は約 1 日間室温で自然乾燥させ， ある程度の強度が得られてから, 乾燥器に入れ約 2 日間乾燥させ たものを使用した。炭層の厚さは $4 \mathrm{~cm}$, 坑道の直径は $5 \mathrm{~cm}$, 模型試 料全体の大きさは $40 \mathrm{~cm} \times 40 \mathrm{~cm} \times 40 \mathrm{~cm}$ である。応力解放ボーリング 孔は引立面に，坑道軸と平行な方向へ 2 本作孔した。その長さは $10 \mathrm{~cm}$, 孔径は $8 \mathrm{~mm}$ である。切羽面でのボーリング孔の配置を図 了に示す。また, 想定した切羽 (原型) と模型化した切羽の対応 例を表 1 に示す。模型岩盤（石高建材）と炭層は破砕帯をはさむ ように積み上げた。

\section{$2 \cdot 3$ 仕上げ・加圧・作孔}

模型坑道およびボーリング孔は特製のハンドドリルを用いて, 装置加圧状態下でそれぞれ掘進，作孔した。仕上げ・加圧・作孔 の具体的方法は既報 $[4] に$ 詳しく述べられている。

\section{3. 応力 測 定}

応力分布は，坑道下盤である石膏建材に貼った歪ゲージにより， 垂直応力を測定した。歪ゲージは，炭層の真下にあたる下艋に垂 直な面で切断して, 図4のように坑道軸に直交する方向で破碎帯を はさむように15〜20mm おきに配置した。破砕帯をはさむ両側の 歪ゲージは，破砕帯から $5 \mathrm{~mm}$ の位置に配置した。

孔道を $1 \mathrm{~cm}$ 掘進するごとに, それに応じてボーリング孔をさら に $1 \mathrm{~cm}$ 作孔し，その都度応力分布を測定する。この操作を繰り返

表 1 原型と模型の対応表

\begin{tabular}{l|c|c}
\hline & 原 型 & 模 型 \\
\hline 炭たけ & $3.2 \mathrm{~m}$ & $40 \mathrm{~mm}$ \\
坑道直径 & $4.0 \mathrm{~m}$ & $50 \mathrm{~mm}$ \\
ボーリング孔径 & $64 \mathrm{~cm}$ & $8 \mathrm{~mm}$ \\
ボーリング孔長 & $8.0 \mathrm{~m}$ & $100 \mathrm{~mm}$ \\
\hline 岩盤強度 & $60 \mathrm{MPa}$ & $1.5 \mathrm{MPa}$ \\
炭層強度 & $4 \sim 12 \mathrm{MPa}$ & $0.1 \sim 0.3 \mathrm{MPa}$ \\
破砕帯強度 & $4 \mathrm{MPa}$ & $0.1 \mathrm{MPa}$ \\
かふぶリ压 & $15 \mathrm{MPa}$ & $0.38 \mathrm{MPa}$ \\
\hline
\end{tabular}

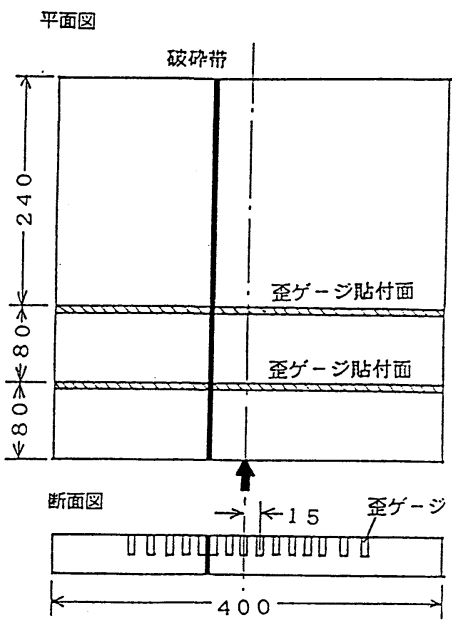

図4导ずみゲージ配置図（単位：mm） し行うと, 引立面との距離が異なる点での応力を測定でき， 1 シ リーズの実験で, 掘進切羽周辺の全体的な応力分布を求めること ができる。応力の值は，かぶり圧に対する測定値の割合 (無次元 応力）で表示した。実際の測定では，主として，装置の中央部に 設けた歪ゲージ列（後列）での剆定値を採用した。坑道掘進用の 作孔器具の構造の都合で, 坑道は前面から $20 \mathrm{~cm}$ 前方までしか掘 進できなかったので, 引立面後方のデータについては, 前列の歪 ゲージの測定值を採用した。

実験データはスキャナーを介してマイクロコンピュータのフロ ッピーディスクに保存した（既報，文献 4)参照）。

\section{4. 実 験 結 果}

本報告で使用する主な記号および用語は次の通りである。

$h \quad:$ 深度 $(\mathrm{m})$

$L \quad$ : 坑道中心軸から破砕帯までの距離 $(\mathrm{cm})$

$W$ : 破砕帯の厚さ $(\mathrm{cm})$

( $W=0 \mathrm{~cm}$ は厚さがなく不連続面だけが存在するこ とを意味する。)

$X$ : 掘進切羽から測定ゲージ列までの距離 $(\mathrm{cm})$

( 掘進切羽前方を正，後方を負とする。）

$R$ : 応力解放度 (後述)

$\gamma:$ 岩盤比重量 $\left(\mathrm{N} / \mathrm{m}^{3}\right)$

$\sigma_{c}:$ 模型炭層強度 $(\mathrm{MPa})$

$\sigma z$ : 測定圧 $(\mathrm{MPa})$

無次元応力：かぶり压に対する測定仕の比

$$
(=\sigma z / \gamma h)
$$

\section{1 応力分布}

測定した応力は無次元応力で表した。

$4 \cdot 1 \cdot 1$ 連続体炭層 不連続面や破碎帯をもたない炭層 (連続体炭層) での坑道断面方向の応力分布例を図 5 と図 6に示 す。いずれもボーリング孔を 2 本作孔してある。模型炭層強度は $\sigma_{c}=0.22 \mathrm{MPa}$ と $\sigma_{c}=0.28 \mathrm{MPa}$ である。奶羽前方ではやや応力が 低下し, また坑道中心から約 $5 \mathrm{~cm}$ 離れた位置に応力集中ゾーン がみられる。しかし炭層強度の大きい（かぶり圧の75\%) 図 6 で は，切羽前方の応力がほとんど解放されていないのがわかる。な お，図中，坑道中心から左右 $2.5 \mathrm{~cm}$ 位置に示した細線は坑道の 幅を示している。

4・1・2 破砕帯の厚さ破砕帯・不連続面が存在する場合 の応力分布例を次に示す。図7は不連続面を有する場合の坑道断 面方向応力分布，図8，図9は破砕帯厚さがそれぞれ $1 \mathrm{~cm}, 2 \mathrm{~cm}$ 


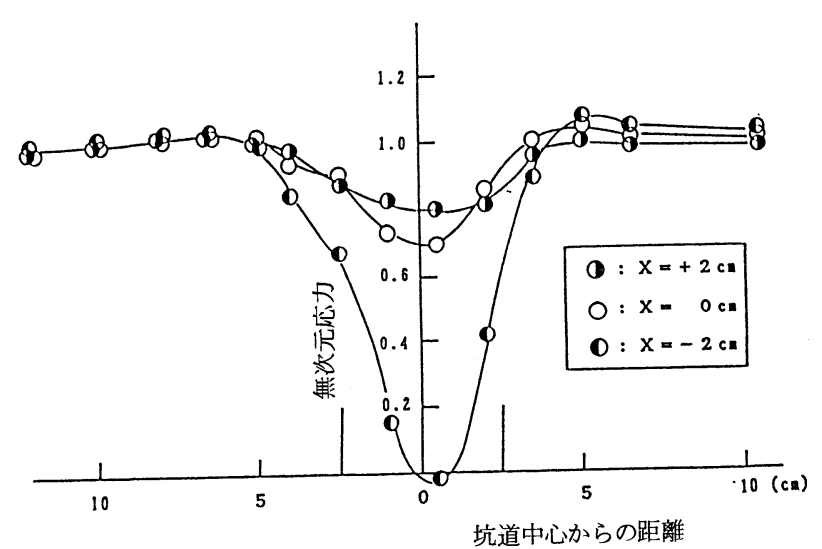

図 5 坑道断面方向応力分布 ( 連続体炭層, $\sigma_{c}=0.22 \mathrm{MPa}$ )

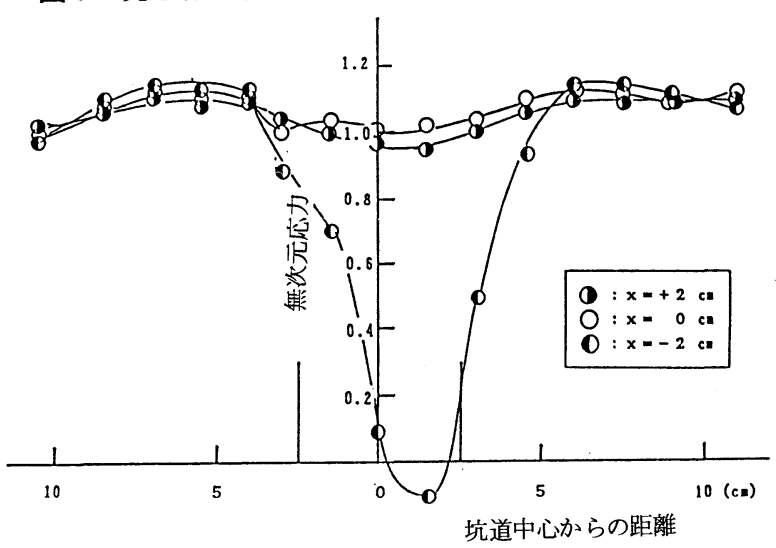

図6 坑道断面方向応力分布 (連続体炭層, $\sigma_{c}=0.28 \mathrm{MPa}$ )

の場合の坑道断面方向応力分布である。坑道中心から破砕帯ま での距離はいずれも $L=3.5 \mathrm{~cm}$ である。

破砕帯をはさんで応力解放ボーリングを実施していない側で は応力変化が小さいかまったく変化していないのがわかる。図 9 では模型炭層強度が $0.29 \mathrm{MPa}$ と大きかったため, 破砕帯の影 響と思われる応力集中が, 応力解放ボーリング実施ゾーンに現 れている。

図10は不連続面を有する場合の坑道中心軸上の応力分布であ る。炭層強度が大きい場合には, 切羽前方に応力集中ゾーンが みられる。図11は破砕帯厚さが異なる場合 $(W=0 \mathrm{~cm}, 1 \mathrm{~cm})$ の坑道中心軸上応力分布である。分布の傾向に大きな盖異はみ られない。

$4 \cdot 1 \cdot 3$ 破砕帯位置 破碎帯位置が $L=2 \mathrm{~cm}$ の場合の坑 道断面方向応力分布を図12に, 坑道中心軸上応力分布を図13に 示す。この場合には，坑道内に破碎帯が現われ，応力解放ボー リングから破砕帯までの距離は $3 \mathrm{~mm}$ である。破碎帯付近に応 力集中がみられるが, これは破碎帯が異常に接近しているため と考えられる。図13に関しては応力分布は坑道中心( 破砕帯から $2 \mathrm{~cm}$ ) と坑道中心から $15 \mathrm{~mm}$ 右側 (破砕帯から $3.5 \mathrm{~cm}$ )の 2 断面で 示してある。これらの分布には大きな違いがある。これは，破碎 帯とボーリング作孔位置が非常に近かったため, 不連続部とボー リング孔が相互に作用し, ボーリング作孔中に炭層内に亀裂が発 生し, 炭層の連綕性が失われ放王部と加圧部が生じたためと思わ れる。

\section{$4 \cdot 2$ 応力解放度}

本実験では炭層内の応力は測定していない。しかし, 炭層内の ボーリング作孔後の応力変化, すなわち, 応力解放の程度は, 今 回測定した下盤での応力変化により評価できると考え, 応力解放

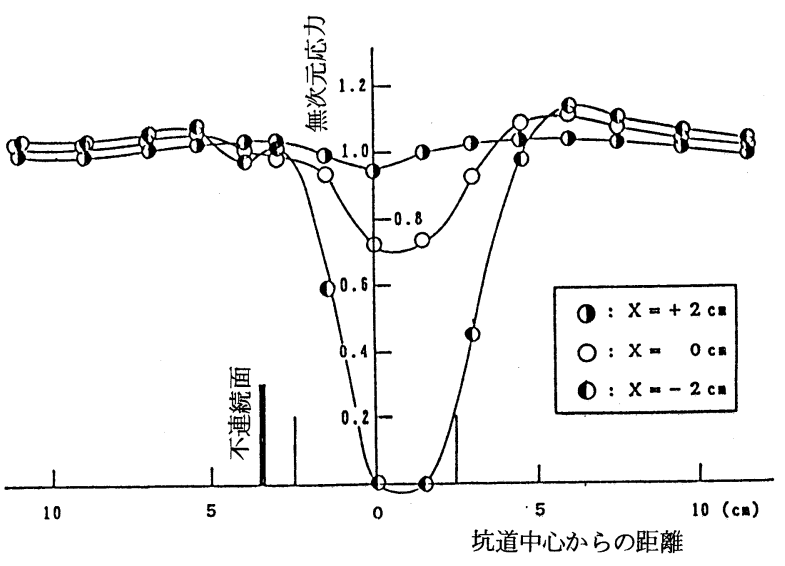

図 7 坑道断面方向応力分布

( $\sigma_{c}=0.28 \mathrm{MPa}, L=3.5 \mathrm{~cm}, W=0 \mathrm{~cm}$ )

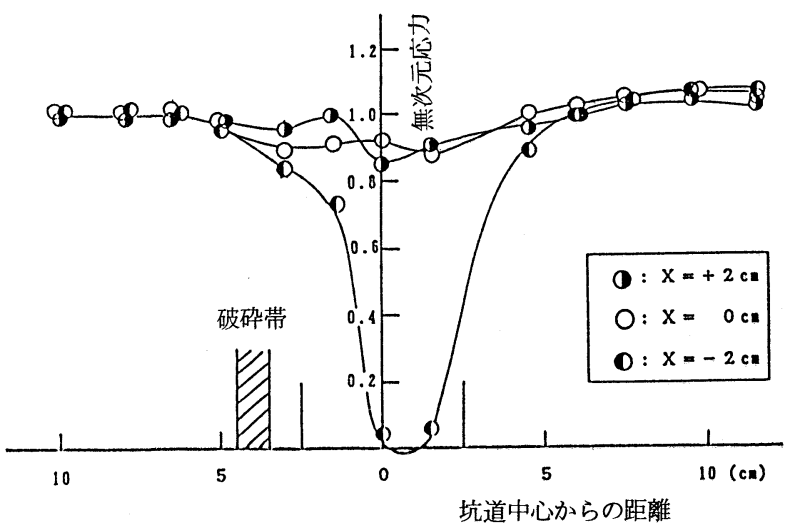

図8 坑道断面方向応力分布

$\left(\sigma_{c}=0.20 \mathrm{MPa}, L=3.5 \mathrm{~cm}, W=1.0 \mathrm{~cm}\right)$

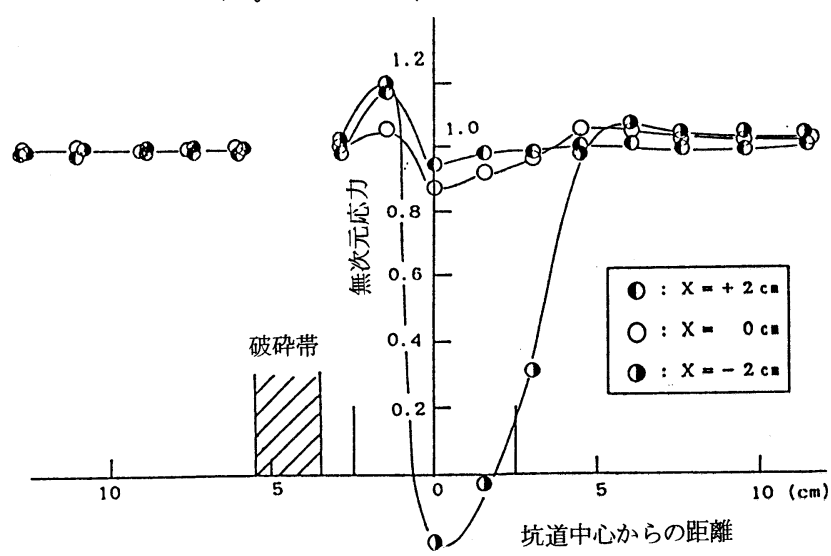

図9坑道断面方向応力分布

$$
\left(\sigma_{c}=0.29 \mathrm{MPa}, L=3.5 \mathrm{~cm}, W=2.0 \mathrm{~cm}\right)
$$

効果を定量的に評価するため, 掘進切羽前方 $2 \mathrm{~cm}$ の位置における 坑道掘准幅での応力分布をもとに, 次のようにして応力解放度を 求めた (図14)。

$$
\text { 応力解放度 } R=100 \times B /(A+B)(\%)
$$

ここで：A：ボーリング作孔後の応力

$$
B \text { : 解放応力 }
$$

掘進坑道前方 $2 \mathrm{~cm}$ 位置を評価基準としたのは, この位置が原 形では $1.6 \mathrm{~m}$ に対応し，1回の発破による掘進長と近い深さにな り, 発破時に誘発されるガス突出の危険性を評価する上で良い指 標となると考えたためである。

図15は模型炭層王縮強度と応力解放度の関係を示している。破 


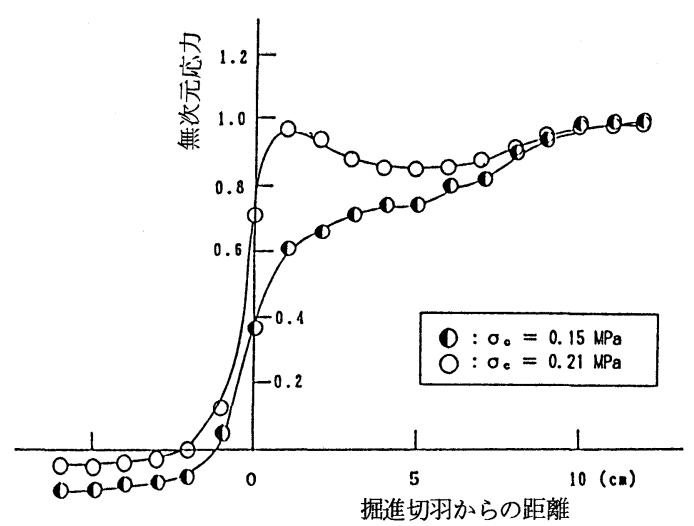

図10 坑道中心軸上応力分布 $(L=3.5 \mathrm{~cm}, W=0 \mathrm{~cm})$

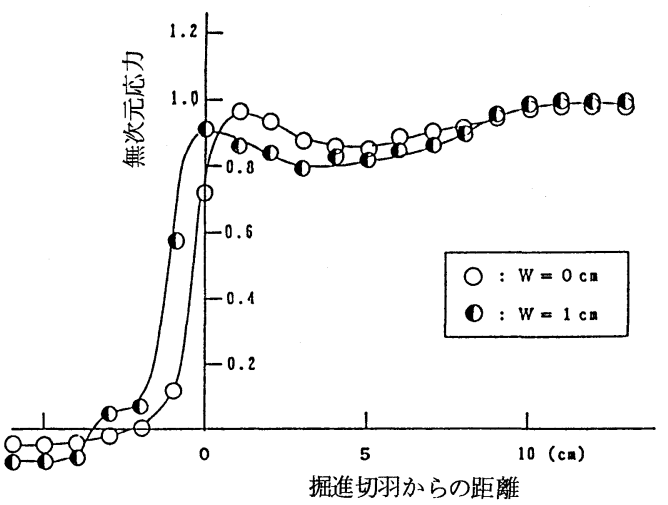

図11 坑道中心軸上応力分布 $\left(\sigma_{c} \fallingdotseq 0.2 \mathrm{MPa}, L=3.5 \mathrm{~cm}\right.$ )

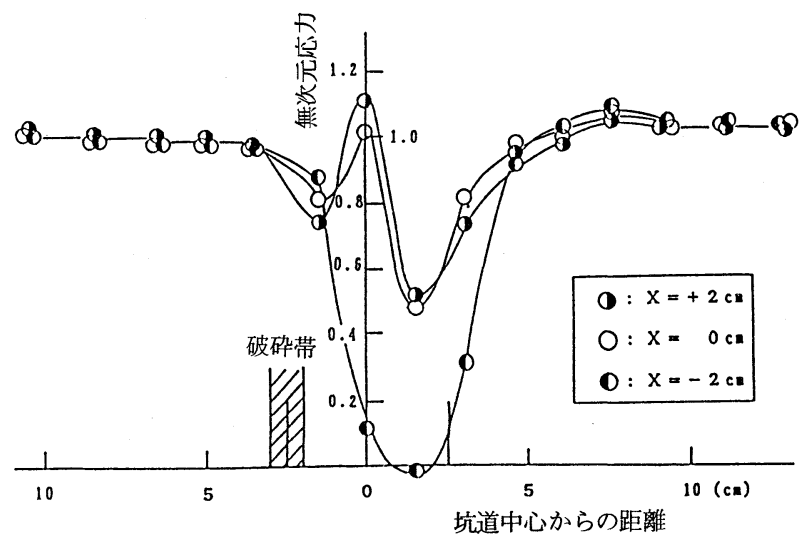

図12 坑道断面方向応力分布 $\left(\sigma_{c}=0.20 \mathrm{MPa}, L=2.0 \mathrm{~cm}, W=1.0 \mathrm{~cm}\right)$

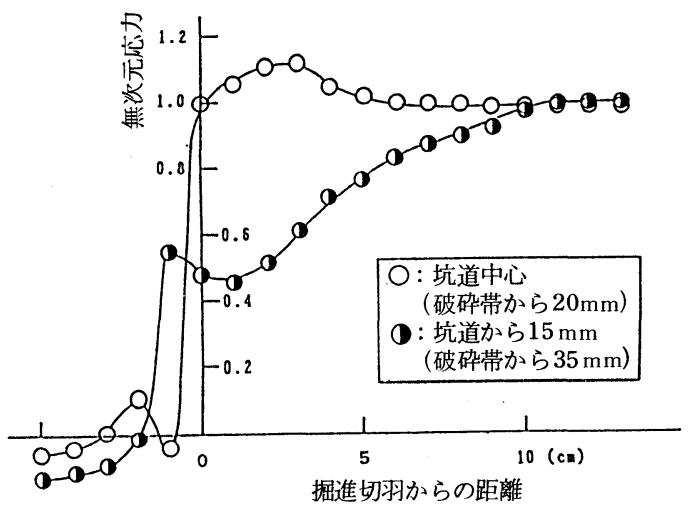

図13 坑道中心軸上応力分布

$\left(\sigma_{c}=0.20 \mathrm{MPa}, L=2.0 \mathrm{~cm}, W=1.0 \mathrm{~cm}\right)$

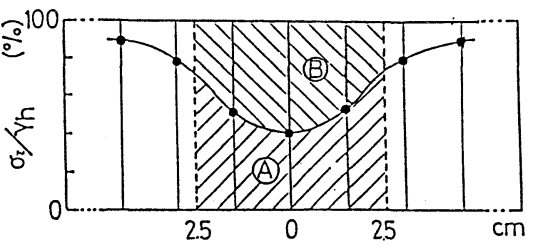

図14 応力解放度の求め方

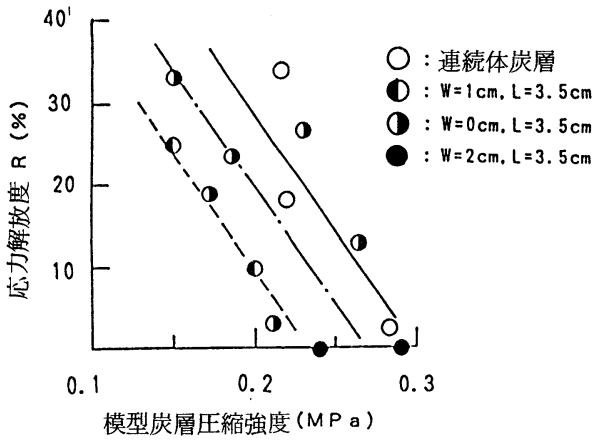

図15模型炭層王縮強度と応力解放度の関係

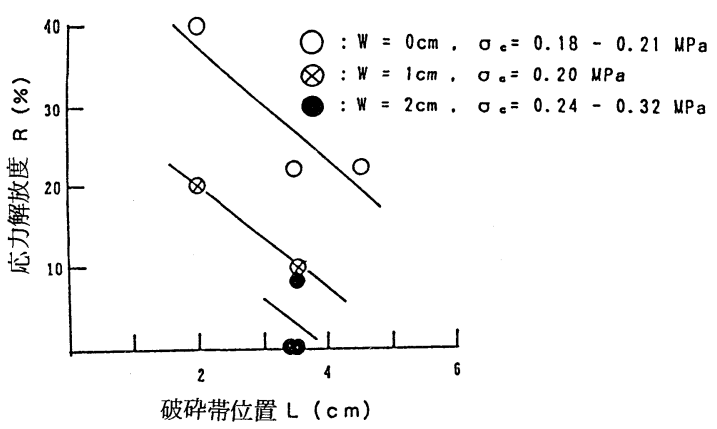

図16 破碎帯位置と応力解放度の関係

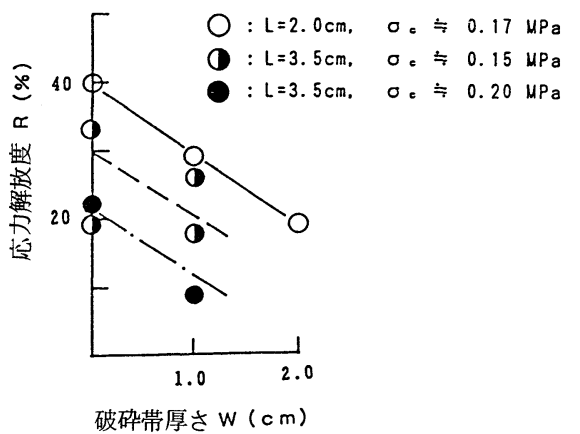

図17 破砕帯厚さと応力解放度の関係

碎帯厚さ $2 \mathrm{~cm}$ を除き, 連続体炭層, 不連続面を有する炭層および破 砕帯厚さ $1 \mathrm{~cm}$ の炭層の順で応力解放は低下している。炭層強度は 応力解放度を決める重要なパラメータであり，さらに，不連続面 や破碎帯の存在は応力解放を妨げることがわかる。

図16は破砕帯位置と応力解放度の関係を示している。破研帯位 置が坑道中心に近いほど応力解放度が大きくなっている。これは, 破砕帯位置が坑道に近いほど, 作孔時に炭層の破壞を促進するた めと考えられる。

図17は破砕帯厚さと応力解放度の関係を示している。破砕帯厚 さが大きくなるにつれて, 応力解放度は減少している。破砕帯は 強度が小さいため, 応力解放ボーリング作孔によるボーリング周 囲への応力再分配が行われず，応力解放度が低下したものと考元 られる。 
5. ま と め

幾何学的縮尺約 $1: 80$ の三次元模型実験装置を用いて, 破碎帯 付近に応力解放先進ボーリングを作孔した場合の, 切羽前方の応 力分布の变化をもとに, 応力解放効果と破砕帯の厚さ, 位置等の 関係を調べた。応力解放効果は筆者が定義した応力解放度により 定量的に評価した。実際の現場では, 破砕帯付近に破砕帯に平行 して坑道を掘進することは少なく，今回の実験条件は多少実際の 条件とは異なる面もあると思われる。今回の実験では, 破砕帯と 応力解放効果の関係を定量的に求めるために, 模型実験で可能な 方法，条件を採用した。

本実験の結果をまとめると次のようになる。 応力分布に関しては,

1) 炭層強度が小さい場合, ボーリング作孔により炭層内の応 力は大きく解放される。

2) 炭層強度が大きい場合，ボーリングを実施しても破砕帯の 影響による応力集中が生じ，応力が解放されないことがある。

3）破碎帯が坑道に非常に接近している場合には, ボーリング 作孔と破砕帯の相互作用で，ボーリング孔間に応力集中が生じる ことがある。
4) 破碎帯の厚さが厚い場合には，破砕帯に対し坑道と反対側 では，まったく応力が解放されないことがある。 応力解放度に関しては,

5）炭層強度は応力解放度を決定する重要なパラメータであり， 強度が大きいほど応力解放度は低下する。

6) 不連粕面，破砕帯が存在すると応力解放度は低下寸る。

7）今回の実験条件の範囲では, 破砕带位置が遠いほど応力解 放度は低下した。

8）破碎帯厚さが大きいほど応力解放度は低下する。

最後に, 本実験の遂行に多くのご支援を頂いた(財)石炭技術研 究所, ならびに, 実験装置の製作と実施に当たり多大な協力を頂 いた東京大学工学部 杉浦哲雄助手と大村昭士助手に感謝の意を 表する。

\section{参 考 文 献}

1) Siebers, U. : Glückauf, $113[18], 899 \sim 903$, (1977)

2）石炭技術研究所：ガス突出対策応力解放総合実証試験成果報告書 (昭和 59 年 4 月)

3）石炭技術研究所：ガス突出対策応力解放総合実証試験成果報告書 (昭和 60 年 5 月)

4）島田荘平：資源・素材学会誌，107[No.13]，965～969，(1991)

\section{:日ニュース}

国連海洋法条約の海底資源開発の規制の改正（日経1992.3.5.)

現在ジャマイカで開催中の国連海洋法条約準備委員会で各国が 規約改正に基本合意し，先進国による海底資源の開発を規制して いる国連の規約が大幅に緩和される見通しで，13日に正式会合で 決定する。

開発規制が解除されると，これまで日本，フランスなど鉱区登 録をしている国は国連への毎年100万\$の拠出（過去の累積分含む）
義務が免除される。

資源の乏しい日本としては深海マンガン鉱床や熱水鉱床などの

探査, 開発計画に弾みがつきそうだと報してている。 今回偶然ロシアWAND AUTOMATION LTD.からDeepsea Mining に関する世界25力国の特許が網羅されている出版物が発行された ので，時宜を得たものと下記にご紹介する。

Reference survey of patent documents of leading industrial countries

"100 INVENTIVE SOLUTIONS FOR DEEPSEA MINING" (methods and apparatus for deepsea mining of solid mineral resources)

Priority and corresponding patent documents reflecting the main trends in development of technical means for deepsea mining of solid mineral resources found in patent files of the USA, West Germany, France, Great Britain, Japan, Switzerland, Italy, Finland, Netherlands, Luxembourg, Australia, Belgium, Canada, Denmark, Spain, Hong Kong, Mexico, Norway, Poland, Sweden, Singapore, New Zealand, South Africa, India and also of the European Patent Office. The volume of the selected priority and corresponding patent documents is more than 700 .

Retrospective period - 25 years (1965 - 1990).

Language of the survey - English (the titles of the patent documents - in English, French and German).

The survey contains 100 topics primary priority patent documents concerning principal technical ideas of deepsea mining of manganese nodules, metalliferrous muds, cobalt crusts, metal enriched fluids etc. Information concerning more than 600 corresponding patent documents in other countries and priority country related patent document can be obtained from topic of respective primary priority patent document.

Each topic includes bibliographic (identification and registration) data priority patent document, abstract of the disclosure based upon the author's patent document content analysis, information concerning corresponding patent documents, and main drawings as well.

The survey includes also the selected numerical index, corresponding documents index, selected classification index, inventors, applicants and grantees list etc. In the appendix to the survey an additional list of the priority and related patent documents excerpted by the analysis of patent documents files of the deepsea mining problem is included.

Produced by WAND AUTOMATION LTD.

Price - $\$ 250$ per copy (in hard currency).

Purchase Order will be sent on your request.

Please contact:

Mail address: Kutuzovsky Pr. 5/3, 2, 135, Moscow 121248 RUSSIA 